\title{
Oxygen-by-sulfur substitutions in glycine: conformational and vibrational effects $\dagger$
}

\author{
Luís A. E. Batista de Carvalho, ${ }^{* a}$ M. Paula M. Marques ${ }^{a b}$ and José J. C. Teixeira-Dias ${ }^{c}$ \\ a Unidade I\&D "Química-Física Molecular”, Faculdade de Ciências e Tecnologia, \\ Universidade de Coimbra, P-3049 Coimbra, Portugal \\ ${ }^{b}$ Departamento de Bioquímica, Faculdade de Ciências e Tecnologia, Universidade de Coimbra, \\ P-3049 Coimbra, Portugal \\ ${ }^{c}$ Departamento de Química, Universidade de Aveiro, P-3810 Aveiro, Portugal
}

\author{
Received (in Cambridge, UK) 24th June 1999, Accepted 31st August 1999
}

\begin{abstract}
Molecular geometries, energies, dipole moments and atomic charges of several conformations of glycine $\left(\mathrm{NH}_{2} \mathrm{CH}_{2} \mathrm{C}(=\mathrm{O}) \mathrm{OH}\right)$ and its oxygen-by-sulfur substituted analogues $\left(\mathrm{NH}_{2} \mathrm{CH}_{2} \mathrm{C}(=\mathrm{O}) \mathrm{SH}, \mathrm{NH}_{2} \mathrm{CH}_{2} \mathrm{C}(=\mathrm{S}) \mathrm{OH}\right.$ and $\mathrm{NH}_{2} \mathrm{CH}_{2} \mathrm{C}(=\mathrm{S}) \mathrm{SH}$ ) were determined by ab initio $\mathrm{MO}$ calculations at the MP2/6-31G** level, and vibrational frequencies, infrared and Raman intensities were evaluated within the harmonic approximation, at the HF/6-31G** level. Profiles for the potential energy and several geometric parameters as a function of the $\mathrm{NC}-\mathrm{C}(=\mathrm{X})(\mathrm{X}=\mathrm{O}, \mathrm{S})$ dihedral angle (C-C internal rotation) were obtained using the $3-21 \mathrm{G}\left(\mathrm{N}^{*}\right)$ basis set. Conformational and vibrational effects of oxygen-by-sulfur substitutions are discussed. In particular, the occurrence of intramolecular close contacts between the $\mathrm{NH}_{2} \mathrm{CH}_{2}-$ and $-\mathrm{C}(=\mathrm{X}) \mathrm{YH}(\mathrm{X}, \mathrm{Y}=\mathrm{O}$ or $\mathrm{S})$ moieties of the molecule is considered, for some of the most stable conformations of each analogue. As a general trend, the results clearly point to the stabilisation of the G/anti forms (:NCC $\left.\cong 60^{\circ}, \mathrm{NCCX} \cong 180^{\circ}\right)$, highlighting the importance of the $\mathrm{N}: \cdots \mathrm{H}(\mathrm{Y})$ and $\mathrm{N}: \cdots \mathrm{S}(\mathrm{H})$ interactions, e.g. in conformers G/anti/s-trans for the thione form $(\mathrm{X}=\mathrm{S})$ and Glanti/s-cis for the thiol one $(\mathrm{Y}=\mathrm{S})$, respectively.
\end{abstract}

\section{Introduction}

Glycine $\left(\mathrm{NH}_{2} \mathrm{CH}_{2} \mathrm{COOH}\right)$, the simplest amino acid and a prototype structural unit for other amino acids and proteins, has been the subject of numerous studies over the years. ${ }^{1-29}$ Its conformational degrees of freedom are related to internal rotations about the $\mathrm{N}-\mathrm{C}, \mathrm{C}-\mathrm{C}$ and $\mathrm{C}-\mathrm{O}$ bonds, which can be described, respectively, by the : $\mathrm{N}-\mathrm{CC}, \mathrm{NC}-\mathrm{C}(=\mathrm{O})$ and $(\mathrm{O}=) \mathrm{C}-\mathrm{OH}$ dihedral angles (: standing for the nitrogen lone pair). These angles can take the following typical values (Fig. 1): i) : $\mathrm{N}-\mathrm{CC}-A\left(\right.$ anti, $\left.180^{\circ}\right), G$ (gauche, $\left.\pm 60^{\circ}\right)$ or $S\left(\right.$ syn, $\left.0^{\circ}\right)$; ii) $\mathrm{NC}-\mathrm{C}(=\mathrm{O})$-anti $\left(180^{\circ}\right)$, skew $\left( \pm 120^{\circ}\right)$ or syn $\left(0^{\circ}\right)$; iii) $(\mathrm{O}=) \mathrm{C}-\mathrm{OH}-\mathrm{s}$-cis $\left(0^{\circ}\right)$ or $s$-trans $\left(180^{\circ}\right)$. A prime is used to denote a negative dihedral angle. Each particular conformation will then be described by the values of : $\mathrm{N}-\mathrm{CC}, \mathrm{NC}-\mathrm{C}(=\mathrm{O})$ and $(\mathrm{O}=) \mathrm{C}-\mathrm{OH}$, in this order: thus, $A /$ syn/s-cis, for instance, refers to the geometry where : $\mathrm{N}-\mathrm{CC}$ is $A, \mathrm{NC}-\mathrm{C}(=\mathrm{O})$ is syn and $(\mathrm{O}=) \mathrm{C}-\mathrm{OH}$ is $s$-cis.

Previously reported microwave studies on glycine yielded S/antils-trans as the predominant form in the gas phase. ${ }^{3,4,6} \mathrm{In}$ this conformation, a hydrogen bond type interaction $\mathrm{N} \cdots \mathrm{HO}$ is formed, leading to the formation of a five-membered ring $\mathrm{N}\left(\mathrm{H}_{2}\right)-\mathrm{C}\left(\mathrm{H}_{2}\right)-\mathrm{C}-\mathrm{O}-\mathrm{H}$. Ab initio $\mathrm{MO}$ calculations ${ }^{1,2}$ as well as joint experimental-theoretical studies, ${ }^{8}$ on the other hand, found $\mathrm{A} / \mathrm{syn} / \mathrm{s}$-cis as the lowest energy conformer for glycine. In this form, a $\mathrm{NH}_{2} \cdots \mathrm{O}(=)$ interaction is formed, closing the five-membered ring $\mathrm{H}_{2} \mathrm{~N}-\mathrm{C}\left(\mathrm{H}_{2}\right)-\mathrm{C}=\mathrm{O}$, with the nitrogen bonded $\mathrm{H}$ atoms standing above and below the ring plane.

A more recent study by electron diffraction techniques on gaseous glycine ${ }^{19}$ has also found $\mathrm{A} / \mathrm{syn} / \mathrm{s}$-cis as the most stable

$\dagger$ Optimized geometries and calculated atomic charges for the conformers of glycine and its oxygen-by-sulfur substituted analogues are available as supplementary data. For direct electronic access see http:// www.rsc.org/suppdata/p2/1999/2507, otherwise available from BLDSC (SUPPL. NO. 57637, pp. 9) or the RSC Library. See Instructions for Authors available via the RSC web page (http:www.rsc.org/authors).

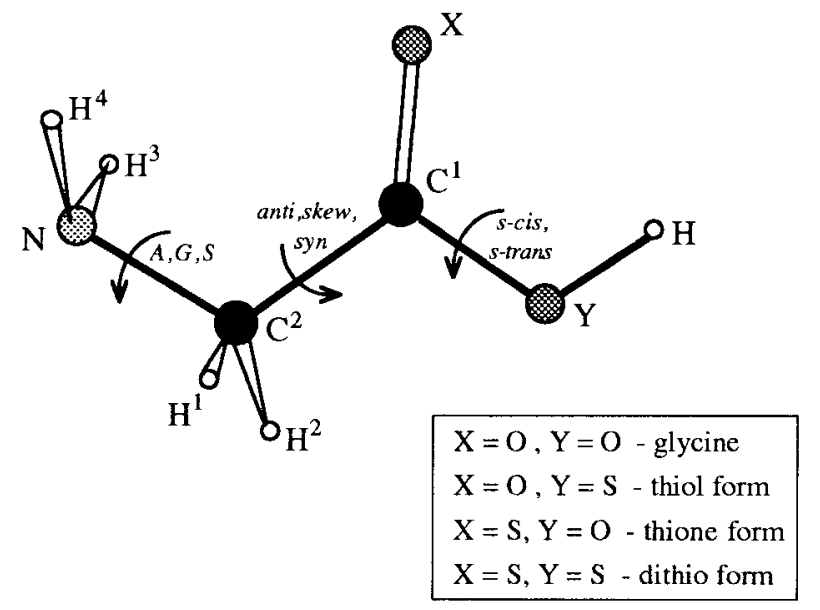

Fig. 1 Schematic representation of the glycine molecule and its sulfur analogues, $\mathrm{NH}_{2} \mathrm{CH}_{2} \mathrm{C}(=\mathrm{X}) \mathrm{YH}(\mathrm{X}, \mathrm{Y}=\mathrm{O}$ or $\mathrm{S})$.

conformation, apart from a minor component probably consisting of a mixture of S/anti/s-trans and A/anti/s-cis structures. It should not be forgotten that the low electric dipole moment of $A / s y n / s$-cis renders its detection by microwave spectroscopy more difficult, which can explain the reported contradictory results. ${ }^{5,8}$ In turn, an infra-red study of glycine isolated in inert gas matrices ${ }^{26}$ led to the detection of some of the conformations predicted by ab initio calculations, while experiments using a free-expansion jet microwave spectrometer ${ }^{27,28}$ allowed the observation of higher energy conformers.

In a thorough ab initio conformational study performed for glycine ${ }^{17}$ it was concluded that S/anti/s-trans and Alanti/s-cis forms have higher energies than their gauche counterparts Glanti/s-trans and G/anti/s-cis. However, sensitivity of the conformational energy differences to the basis set has to be taken into account. Thus, some recent theoretical works have been reported on the ground state potential energy surface of this 
Table 1 Conformational energies for the $\mathrm{NH}_{2} \mathrm{CH}_{2} \mathrm{C}(=\mathrm{X}) \mathrm{YH}(\mathrm{X}, \mathrm{Y}=\mathrm{O}$ or $\mathrm{S})$ molecules

\begin{tabular}{|c|c|c|c|c|c|c|c|}
\hline \multirow[b]{2}{*}{ Molecule } & & \multicolumn{4}{|c|}{ Energy differences $/ \mathrm{kJ} \mathrm{mol}^{-1 a}$} & \multirow{2}{*}{\multicolumn{2}{|c|}{ Energy barriers $/ \mathrm{kJ} \mathrm{mol}^{-1}$}} \\
\hline & & $3-21 G\left(N^{*}\right)$ & $3-21 G\left(N^{*}, S^{*}\right)$ & $6-31 G^{* *}$ & MP2/6-31G** & & \\
\hline \multirow[t]{7}{*}{$\mathrm{NH}_{2} \mathrm{CH}_{2} \mathrm{C}(=\mathrm{O}) \mathrm{OH}$} & Alantils-cis & 7.58 & - & 8.00 & 6.95 & \multirow{7}{*}{$\begin{array}{l}\text { Alsyn/s-cis } \rightarrow \\
\rightarrow \text { Alanti/s-cis } \\
\text { Glanti/s-trans } \rightarrow \\
\rightarrow G^{\prime} / \text { antils-trans }\end{array}$} & \\
\hline & A/syn/s-trans & 34.19 & - & 28.96 & 26.09 & & $19.10^{b}$ \\
\hline & Alanti/s-trans & 48.23 & - & 37.53 & 33.50 & & \\
\hline & G/syn/s-cis & 11.88 & - & 8.57 & 8.52 & & $0.99^{c}$ \\
\hline & G/skew'/s-cis & 15.07 & - & 13.02 & 12.82 & & \\
\hline & G/syn/s-trans & ${ }^{d}$ & - & 38.42 & 35.64 & & \\
\hline & Glantils-trans & 16.44 & - & 12.58 & 5.87 & & \\
\hline \multirow[t]{7}{*}{$\mathrm{NH}_{2} \mathrm{CH}_{2} \mathrm{C}(=\mathrm{O}) \mathrm{SH}$} & Alantils-cis & 1.96 & 2.68 & 4.16 & 0.78 & \multirow{7}{*}{$\begin{array}{l}\text { A/syn/s-cis } \rightarrow \\
\rightarrow \text { Alanti/s-cis } \\
\text { Glanti/s-trans } \rightarrow \\
\rightarrow G^{\prime} / \text { antils-trans } \\
\text { Glanti/s-cis } \rightarrow \\
\rightarrow G^{\prime} / \text { lantils-cis }\end{array}$} & \\
\hline & A/syn/s-trans & 13.35 & 9.14 & 5.87 & 6.40 & & $14.13^{b}$ \\
\hline & Alanti/s-trans & 29.02 & 25.93 & 20.71 & 21.42 & & \\
\hline & G/syn/s-cis & 12.38 & 11.92 & 9.00 & 8.87 & & $2.87^{c}$ \\
\hline & Glantils-cis & 6.04 & -0.15 & 4.38 & 1.92 & & \\
\hline & G/syn/s-trans & 26.96 & $-^{d}$ & 16.70 & 17.48 & & $2.19^{c}$ \\
\hline & Glantils-trans & 14.57 & 10.14 & 8.74 & 5.72 & & \\
\hline \multirow[t]{7}{*}{$\mathrm{NH}_{2} \mathrm{CH}_{2} \mathrm{C}(=\mathrm{S}) \mathrm{OH}$} & Alantils-cis & 7.21 & 6.86 & 7.40 & 7.91 & \multirow{7}{*}{$\begin{array}{l}\text { A/syn/s-cis } \rightarrow \\
\rightarrow \text { Alantils-cis } \\
\text { Glanti/s-trans } \rightarrow \\
\rightarrow G^{\prime} / \text { antils-trans }\end{array}$} & \\
\hline & A/syn $/$ s-trans & 36.17 & 39.52 & 31.36 & 25.95 & & $15.51^{b}$ \\
\hline & Alanti/s-trans & 46.35 & 45.80 & $-^{d}$ & 31.92 & & \\
\hline & G/syn/s-cis & 17.19 & 16.48 & 12.63 & 11.65 & & $0.51^{c}$ \\
\hline & G/skew'/s-cis & 17.39 & 16.60 & 13.21 & 13.17 & & \\
\hline & G/syn/s-trans & 56.59 & 54.92 & 46.04 & 39.98 & & \\
\hline & Glantils-trans & 8.75 & 9.94 & 8.64 & 0.77 & & \\
\hline \multirow[t]{7}{*}{$\mathrm{NH}_{2} \mathrm{CH}_{2} \mathrm{C}(=\mathrm{S}) \mathrm{SH}$} & Alantils-cis & 4.19 & 3.25 & 4.80 & 3.43 & \multirow{7}{*}{$\begin{array}{l}\text { A/syn/s-cis } \rightarrow \\
\rightarrow \text { Alantils-cis } \\
\text { Glanti/s-trans } \rightarrow \\
\rightarrow G^{\prime} / \text { antils-trans } \\
\text { Glanti/s-cis } \rightarrow \\
\rightarrow G^{\prime} / \text { antils-cis }\end{array}$} & \\
\hline & A/syn/s-trans & 11.25 & 6.06 & 5.23 & 3.79 & & $10.98^{b}$ \\
\hline & Alantils-trans & 27.49 & 22.36 & 20.94 & 18.53 & & \\
\hline & G/syn/s-cis & 17.56 & 17.47 & 12.45 & 11.69 & & $3.76^{c}$ \\
\hline & Glantils-cis & 5.86 & 0.13 & 3.58 & 2.16 & & \\
\hline & G/syn/s-trans & 30.68 & 25.69 & 20.58 & 18.82 & & $3.26^{c}$ \\
\hline & Glanti/s-trans & 8.84 & 5.08 & 5.81 & 1.62 & & \\
\hline
\end{tabular}

${ }^{a}$ Relative to the most stable conformer A/syn/s-cis. ${ }^{b}$ Calculated at the $3-21 \mathrm{G}\left(\mathrm{N}^{*}\right)$ level. ${ }^{c}$ Calculated at the MP2/6-31G** level. ${ }^{d}$ Does not converge with this basis set.

amino acid, exploring the effect of basis set improvement and better treatment of electron correlation, from the MP2, MP3 and MP4 optimizations of Császár, ${ }^{24}$ to the studies of $\mathrm{Hu}$ et al. at the CISD/DZP level of theory, ${ }^{25}$ and Nguyen et al. using density functional theory (DFT). ${ }^{29}$

The present work deals with conformational and vibrational effects of oxygen-by-sulfur substitutions in glycine. $\mathrm{NH}_{2} \mathrm{CH}_{2} \mathrm{C}(=\mathrm{X}) \mathrm{YH}(\mathrm{X}, \mathrm{Y}=\mathrm{O}$ or $\mathrm{S})$ molecules $((\mathrm{O}, \mathrm{O}),(\mathrm{O}, \mathrm{S})$, $(\mathrm{S}, \mathrm{O})$ and $(\mathrm{S}, \mathrm{S}))$ are studied by ab initio MO calculations, at the MP2/6-31G** level, and the C-C internal rotation is analysed using the $3-21 \mathrm{G}\left(\mathrm{N}^{*}\right)$ basis set. Characterisation of several intramolecular interactions, namely $\mathrm{N}: \cdots \mathrm{Y}, \mathrm{N}: \cdots \mathrm{HY}$, $(\mathrm{N}) \mathrm{H}_{2} \cdots \mathrm{X}=$ and $(\mathrm{N}) \mathrm{H}_{2} \cdots \mathrm{Y}$, and evaluation of their relative contributions are particularly important for understanding the conformational behaviour of $\alpha$-amino substituted carbonylic and thiocarbonylic compounds. In particular, these interactions are of crucial importance in enzymatic processes involving this kind of molecule. The fact that oxygen-by-sulfur substitutions have been systematically used in Raman spectroscopic biochemical studies, with the aim of generating chromophores acting as resonance Raman probes in the active sites of enzyme-substrate complexes, ${ }^{30,31}$ adds to the practical relevance of the study herein carried out.

\section{Computational methods}

$A b$ initio MO calculations were carried out using the GAUSSIAN $94^{32}$ program, with the split valence basis sets $3-21 \mathrm{G}+\mathrm{d}\left(\zeta_{\mathrm{N}}=0.8\right)\left(\right.$ abbreviated $\left.3-21 \mathrm{G}\left(\mathrm{N}^{*}\right)\right), 3-21 \mathrm{G}+\mathrm{d}\left(\zeta_{\mathrm{N}}=0.8\right.$; $\left.\zeta_{\mathrm{s}}=0.65\right) \quad\left(\text { abbreviated } 3-21 \mathrm{G}\left(\mathrm{N}^{*}, \mathrm{~S}^{*}\right)\right)^{33,34}$ and $6-31 \mathrm{G}^{* *}, 35,36$ at the Hartree-Fock (HF) level, and 6-31G** using secondorder Möller-Plesset perturbation theory (MP2). Molecular geometries were fully optimized by the Berny algorithm using redundant internal coordinates: ${ }^{37}$ the bond lengths to within ca. $0.1 \mathrm{pm}$ and the bond angles to within $c a .0 .1^{\circ}$. The final rootmean-square (rms) gradients were always less than $3 \times 10^{-4}$ hartree bohr ${ }^{-1}$ or hartree radian $^{-1}$.

In the compounds under study, the relevant dihedral angles (Fig. 1) should adopt values around $0^{\circ}, \pm 60^{\circ}$ or $180^{\circ}$ for : $\mathrm{N}-\mathrm{CC} ; 0^{\circ}, \pm 120^{\circ}$ or $180^{\circ}$ for $\mathrm{NC}-\mathrm{C}(=\mathrm{X})$; and $0^{\circ}$ or $180^{\circ}$ for $(\mathrm{X}=\mathrm{C})-\mathrm{YH}$. In order to study the $\mathrm{C}-\mathrm{C}$ internal rotation, the geometries were optimized for different fixed $\mathrm{NC}-\mathrm{C}(=\mathrm{X})$ dihedral angles.

Calculation of the vibrational spectra was carried out at the HF/6-31G** level, as inclusion of electronic correlation was found not to pay for extra computing time and disk space requirements.

The graphical representation of the potential-energy and structural parameter variations were based on least-squares fitted Fourier-type functions of a torsional angle [eqn. (1)],

$$
P=P_{0}+\Sigma_{(n=1,3)} \frac{1}{2} P_{n}[1-\cos (n \theta)]
$$

where $\theta$ is the $\mathrm{NC}-\mathrm{C}(=\mathrm{X})(\mathrm{X}=\mathrm{O}$ or $\mathrm{S})$ dihedral angle and $P$ are functional values that may correspond to potential energy $(V)$, bond distance or bond angle differences relative to a reference value $\left(P_{0}\right.$ is the parameter corresponding to a $\mathrm{NC}-\mathrm{C}(=\mathrm{X})$ angle of $\left.0^{\circ}\right)$.

\section{Results and discussion}

\section{Stable conformations and intramolecular interactions}

Table 1 lists the conformational energy differences of the distinct conformers of the $\mathrm{NH}_{2} \mathrm{CH}_{2} \mathrm{C}(=\mathrm{X}) \mathrm{YH}$ molecules $(\mathrm{X}, \mathrm{Y}=$ $\mathrm{O}$ or S) (Fig. 2), as well as the energy barriers corresponding to some of their elementary internal rotations. Conformational energy minima, not separated by more than $15 \mathrm{~kJ} \mathrm{~mol}^{-1}$ from the most stable conformer, A/syn/s-cis, are shown in Fig. 3. 


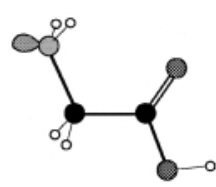

A/syn/s-cis

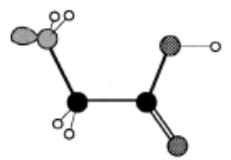

A/antils-cis

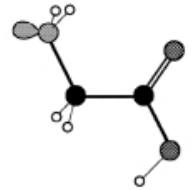

A/syn/s-trans

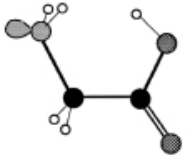

A/anti/s-trans

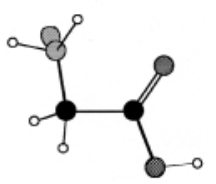

G/syn/s-cis

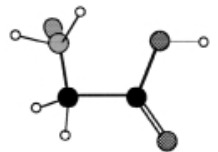

G/antils-cis

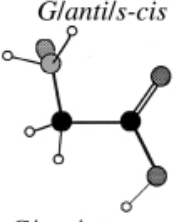

G/syn/s-trans

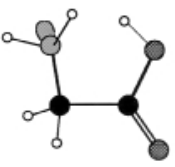

G/anti/s-trans
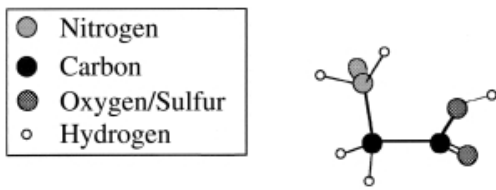

G/skew's-cis
Fig. 2 Schematic representation of the different conformations found for the $\mathrm{NH}_{2} \mathrm{CH}_{2} \mathrm{C}(=\mathrm{X}) \mathrm{YH}(\mathrm{X}, \mathrm{Y}=\mathrm{O}$ or $\mathrm{S})$ molecules.

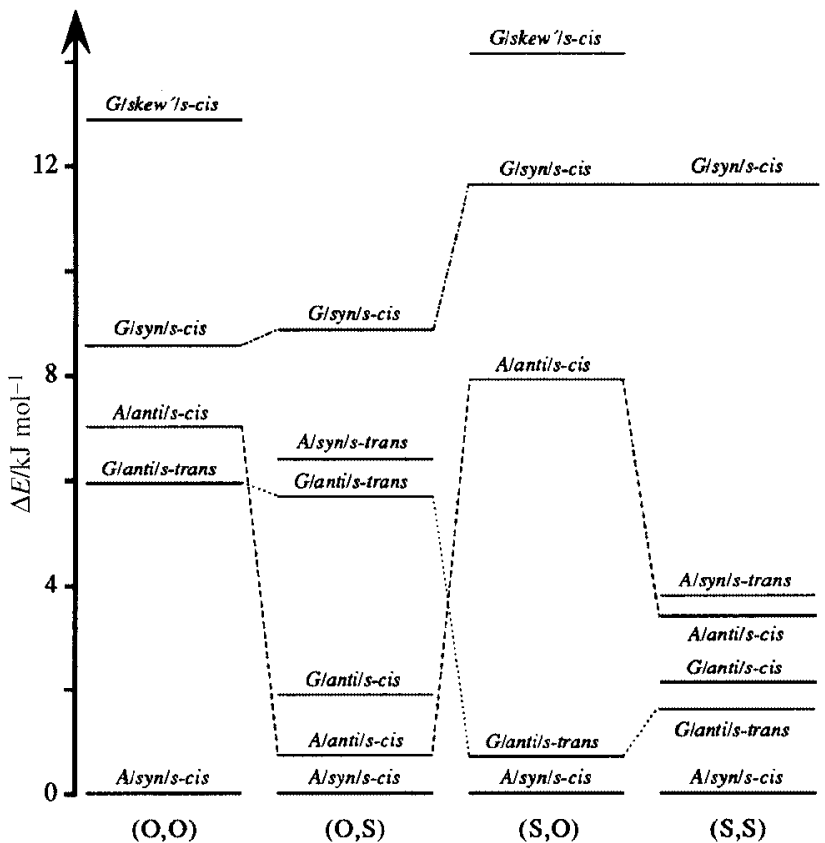

Fig. 3 Schematic representation of the relative energies of the most stable conformers of the $\mathrm{NH}_{2} \mathrm{CH}_{2} \mathrm{C}(=\mathrm{X}) \mathrm{YH}(\mathrm{X}, \mathrm{Y}=\mathrm{O}$ or $\mathrm{S})$ molecules (at the MP2/6-31G** level of calculation).

It was verified that all the : $\mathrm{N}-\mathrm{CC}$ syn $(\mathrm{S})$ conformations are first order saddle points. Tables 2 and 3 comprise the optimized geometries, as well as the Mulliken atomic charges and dipole moments calculated for the $\mathrm{A} / \mathrm{syn} / \mathrm{s}$-cis conformers.

Oxygen-by-sulfur substitutions were found to cause shifts in the conformational energy levels of the molecules under study. In some cases, these shifts are sensitive to a particular type of substitution, either in the $\mathrm{X}$ or the $\mathrm{Y}$ atom. Thus, the energy difference between conformers $\mathrm{G} / \mathrm{syn} / \mathrm{s}$-cis and $\mathrm{A} / \mathrm{syn} / \mathrm{s}$-cis, i.e., $(G-A) /$ syn/s-cis $-8.5 \mathrm{~kJ} \mathrm{~mol}^{-1}$ for $(\mathrm{O}, \mathrm{O}), 8.9$ for $(\mathrm{O}, \mathrm{S}), 11.7$ for (S,O) and 11.7 for $(\mathrm{S}, \mathrm{S})$ (Table 1, Fig. 3) - is almost insensitive to the oxygen-by-sulfur substitution in the $\mathrm{Y}$ position, but it increases by $c a .3 \mathrm{~kJ} \mathrm{~mol}^{-1}$ due to the presence of a thione sulfur atom. In fact, for $\mathrm{X}=\mathrm{O}$ there is evidence of a significant stabilising attractive $=\mathrm{O} \cdots \mathrm{H}(\mathrm{N})$ interaction (favoured by the
Table 2 Optimized geometries for the most stable conformer $($ A/syn/s-cis $)$ of the $\mathrm{NH}_{2} \mathrm{CH}_{2} \mathrm{C}(=\mathrm{X}) \mathrm{YH}(\mathrm{X}, \mathrm{Y}=\mathrm{O}$ or $\mathrm{S})$ molecules $^{a}$

\begin{tabular}{|c|c|c|c|c|}
\hline & $(\mathrm{O}, \mathrm{O})$ & $(\mathrm{O}, \mathrm{S})$ & $(\mathrm{S}, \mathrm{O})$ & $(\mathrm{S}, \mathrm{S})$ \\
\hline \multicolumn{5}{|c|}{ Bond lengths/pm } \\
\hline$C^{1}=X$ & 121.8 & 121.8 & 162.9 & 162.8 \\
\hline$C^{1}-C^{2}$ & 151.7 & 152.6 & 151.7 & 153.0 \\
\hline $\mathrm{C}^{1}-\mathrm{Y}$ & 135.9 & 179.9 & 134.8 & 176.0 \\
\hline $\mathrm{Y}-\mathrm{H}$ & 97.1 & 133.2 & 97.2 & 133.2 \\
\hline $\mathrm{C}^{2}-\mathrm{H}^{1}$ & 109.1 & 109.2 & 109.3 & 109.3 \\
\hline $\mathrm{C}^{2}-\mathrm{H}^{2}$ & 109.1 & 109.2 & 109.3 & 109.3 \\
\hline $\mathrm{N}-\mathrm{C}^{2}$ & 145.0 & 144.8 & 144.5 & 144.4 \\
\hline $\mathrm{N}-\mathrm{H}^{3}$ & 101.5 & 101.4 & 101.4 & 101.5 \\
\hline $\mathrm{N}-\mathrm{H}^{4}$ & 101.5 & 101.4 & 101.4 & 101.5 \\
\hline \multicolumn{5}{|l|}{ Bond angles $/^{\circ}$} \\
\hline$C^{2}-C^{1}=X$ & 125.4 & 123.4 & 126.5 & 124.1 \\
\hline $\mathrm{X}=\mathrm{C}^{1}-\mathrm{Y}$ & 123.3 & 123.0 & 124.2 & 124.9 \\
\hline $\mathrm{C}^{1}-\mathrm{Y}-\mathrm{H}$ & 105.7 & 93.2 & 107.0 & 95.6 \\
\hline $\mathrm{C}^{1}-\mathrm{C}^{2}-\mathrm{H}^{1}$ & 107.8 & 108.0 & 106.8 & 107.4 \\
\hline $\mathrm{C}^{1}-\mathrm{C}^{2}-\mathrm{H}^{2}$ & 107.8 & 108.0 & 106.8 & 107.4 \\
\hline $\mathrm{N}-\mathrm{C}^{2}-\mathrm{C}^{1}$ & 114.8 & 114.6 & 117.7 & 117.5 \\
\hline $\mathrm{C}^{2}-\mathrm{N}-\mathrm{H}^{3}$ & 108.6 & 108.9 & 109.1 & 109.2 \\
\hline $\mathrm{C}^{2}-\mathrm{N}-\mathrm{H}^{4}$ & 108.6 & 108.9 & 109.1 & 109.2 \\
\hline $\mathrm{C}^{2}-\mathrm{C}^{1}-\mathrm{Y}$ & 111.3 & 113.6 & 109.3 & 111.0 \\
\hline \multicolumn{5}{|c|}{ Dihedral angles $/^{\circ}$} \\
\hline $\mathrm{H}^{1}-\mathrm{C}^{2}-\mathrm{C}^{1}=\mathrm{X}$ & -122.9 & -122.7 & -123.5 & -123.0 \\
\hline $\mathrm{H}^{2}-\mathrm{C}^{2}-\mathrm{C}^{1}=\mathrm{X}$ & 122.9 & 122.7 & 123.5 & 123.0 \\
\hline $\mathrm{N}-\mathrm{C}^{2}-\mathrm{C}^{1}=\mathrm{X}$ & 0.0 & 0.0 & 0.0 & 0.0 \\
\hline $\mathrm{H}^{3}-\mathrm{N}-\mathrm{C}^{2}-\mathrm{C}^{1}$ & 56.7 & 57.0 & 57.3 & 57.3 \\
\hline $\mathrm{H}^{4}-\mathrm{N}-\mathrm{C}^{2}-\mathrm{C}^{1}$ & -56.7 & -57.0 & -57.3 & -57.3 \\
\hline $\mathrm{H}-\mathrm{Y}-\mathrm{C}^{1}-\mathrm{C}^{2}$ & 180.0 & 180.0 & 180.0 & 180.0 \\
\hline
\end{tabular}

${ }^{a}$ The atoms are numbered according to Fig. 1 .

Table 3 Atomic charges and dipole moments $(\mu)$ for the most stable conformer $(A / s y n / s-c i s)$ of the $\mathrm{NH}_{2} \mathrm{CH}_{2} \mathrm{C}(=\mathrm{X}) \mathrm{YH}(\mathrm{X}, \mathrm{Y}=\mathrm{O}$ or $\mathrm{S})$ molecules

\begin{tabular}{lccrr}
\hline & $(\mathrm{O}, \mathrm{O})$ & $(\mathrm{O}, \mathrm{S})$ & $(\mathrm{S}, \mathrm{O})$ & $(\mathrm{S}, \mathrm{S})$ \\
\hline Atomic charge/e $^{a}$ & & & \\
$\mathrm{C}^{1}$ & 0.727 & 0.320 & 0.250 & -0.215 \\
$\mathrm{X}\left(=\mathrm{C}^{1}\right)$ & -0.579 & -0.519 & -0.228 & -0.147 \\
$\mathrm{C}^{2}$ & -0.120 & -0.118 & -0.071 & -0.059 \\
$\mathrm{Y}(-\mathrm{H})$ & -0.611 & 0.014 & -0.562 & 0.109 \\
$\mathrm{H}(-\mathrm{Y})$ & 0.371 & 0.093 & 0.387 & 0.093 \\
$\mathrm{H}^{1}$ & 0.166 & 0.163 & 0.170 & 0.165 \\
$\mathrm{H}^{2}$ & 0.166 & 0.163 & 0.170 & 0.165 \\
$\mathrm{~N}$ & -0.675 & -0.675 & -0.680 & -0.677 \\
$\mathrm{H}^{3}$ & 0.278 & 0.280 & 0.282 & 0.283 \\
$\mathrm{H}^{4}$ & 0.278 & 0.280 & 0.282 & 0.283 \\
$\mu / \mathrm{D}^{d}$ & 1.36 & 0.99 & 1.47 & 1.31 \\
${ }^{a} \mathrm{e}=1.6021982 \times 10^{-19} \mathrm{C}$. & \\
\end{tabular}

large negative charge on the oxygen atom), leading to a rotation of the amine group and an approach between $(\mathrm{N}) \mathrm{H}^{3}$ and $\mathrm{O}=-$ $\mathrm{H}^{3} \mathrm{NC}^{2} \mathrm{C}^{1}$ ca. $-46^{\circ}, \mathrm{NC}^{2} \mathrm{C}^{1}=\mathrm{O}$ ca. $27^{\circ}, \mathrm{H}^{3} \cdots \mathrm{O}=c a .240 \mathrm{pm}$ while the sum of the corresponding van der Waals radii is equal to $260 \mathrm{pm}$. For the $(\mathrm{S}, \mathrm{O})$ and $(\mathrm{S}, \mathrm{S})$ molecules, in turn, this conformational rearrangement is not as significant $-\mathrm{H}^{3} \mathrm{NC}^{2} \mathrm{C}^{1}$ ca. $-56^{\circ}, \mathrm{H}^{3} \cdots \mathrm{S}=c a .270 \mathrm{pm}$ (sum of the van der Waals radii $305 \mathrm{pm})$.

Similarly, the (G/anti/s-trans $)-(A /$ syn $/$ s-cis $)$ energy difference $-5.9 \mathrm{~kJ} \mathrm{~mol}^{-1}$ for $(\mathrm{O}, \mathrm{O}), 5.7$ for $(\mathrm{O}, \mathrm{S}), 0.8$ for $(\mathrm{S}, \mathrm{O})$ and 1.6 for (S,S) (Table 1, Fig. 3) - discriminates against oxygenby-sulfur substitutions in the same way as in the previous case: $(\mathrm{O}, \mathrm{O}),(\mathrm{O}, \mathrm{S})$ vs. $(\mathrm{S}, \mathrm{O}),(\mathrm{S}, \mathrm{S})$. It was verified that this conformational energy difference is reduced by 4 to $5 \mathrm{~kJ} \mathrm{~mol}^{-1}$ when a thione sulfur atom is introduced in the molecule, for an anti $\mathrm{NC}-\mathrm{C}(=\mathrm{X})$ dihedral angle. In fact, for $\mathrm{X}=\mathrm{S}$ the steric repulsion 
between $\mathrm{N}$ and $\mathrm{X}$ leads to a relative stabilisation of the Glantils-trans form, where these two atoms stand well apart (Fig. 2). Also, the effect of electronic correlation, detected by comparing the HF/6-31G** and MP2/6-31G** energy values (Table 1), is worth noticing, as introduction of correlation leads to a clear stabilisation of the $\mathrm{X}=\mathrm{S}$ molecules, i.e., distinguishes between $(\mathrm{O}, \mathrm{O})$ and $(\mathrm{O}, \mathrm{S})$ systems vs. $(\mathrm{S}, \mathrm{O})$ and $(\mathrm{S}, \mathrm{S})$.

On the other hand, conformation A/syn/s-trans is strongly stabilised by the introduction of a thiol atom. In fact, the corresponding energy differences from the most stable conformer, $A / s y n / s$-cis, are: $26.1 \mathrm{~kJ} \mathrm{~mol}^{-1}$ for $(\mathrm{O}, \mathrm{O}), 6.4$ for $(\mathrm{O}, \mathrm{S})$, 26.0 for $(\mathrm{S}, \mathrm{O})$ and 3.8 for $(\mathrm{S}, \mathrm{S})$ (Table 1). These values highlight the fact that the energy difference for this $s$-cis $\rightarrow$ s-trans rearrangement is substantially lowered when $\mathrm{Y}$ is a sulfur atom, thus suggesting a reduction in the $\mathrm{C}-\mathrm{Y}$ double bond character, i.e. a decrease of the mesomeric effect in the thiol analogues, due to the lower conjugating properties of the sulfur $3 p$ orbitals relative to the oxygen $2 \mathrm{p}$ orbitals. This gives rise to a weaker $\mathrm{S}-\mathrm{H} \cdots \mathrm{X}$ intramolecular hydrogen bond interaction as compared to the $\mathrm{O}-\mathrm{H} \cdots \mathrm{X}$ one, and a smaller stabilisation of the $s$-cis conformations.

In contrast to the $(\mathrm{O}, \mathrm{S})$ and $(\mathrm{S}, \mathrm{S})$ systems, the G/anti/s-cis conformation was found not to be an energy minimum for the $(\mathrm{O}, \mathrm{O})$ and $(\mathrm{S}, \mathrm{O})$ molecules. Instead, the similar geometry $\mathrm{G} / \mathrm{skew}^{\prime} / \mathrm{s}$-cis was obtained as a conformer for the latter. In fact for $\mathrm{Y}=\mathrm{O}$ there is both a $\mathrm{N}: \cdots \mathrm{Y}$ repulsive interaction and an attractive $(\mathrm{N}) \mathrm{H}^{3} \cdots \mathrm{Y}$ one, reflected in the rotation of the $\mathrm{C}(=\mathrm{X}) \mathrm{YH}$ molecular fragment (leading to a skew' $\mathrm{NCC}=\mathrm{X}$ angle), $\mathrm{H}^{3} \cdots \mathrm{Y}$ being equal to $242 \mathrm{pm}$ while the sum of the corresponding van der Waals radii is $260 \mathrm{pm}$. When $\mathrm{Y}=\mathrm{S}$ a N: $\cdots \mathrm{S}$ close contact occurs (Fig. 2), which is responsible for the stabilisation of the Glantils-cis form. This approach between the nitrogen lone-pair and the $\mathrm{Y}$ sulfur atom in Glantils-cis, and between the $\mathrm{H}^{3}$ and $\mathrm{Y}$ atoms (for $\mathrm{Y}=\mathrm{O}$ ), is evidenced by the values of the relevant dihedral angles: $\mathrm{NCC}(=\mathrm{O})=164.6^{\circ}, \mathrm{H}^{3} \mathrm{NCC}=-83.8^{\circ}$ and $\mathrm{H}^{4} \mathrm{NCC}=156.6^{\circ}$ for the $(\mathrm{O}, \mathrm{S})$ molecule vs. $\mathrm{NCC}(=\mathrm{O})=-136.5^{\circ}, \mathrm{H}^{3} \mathrm{NCC}=-63.7^{\circ}$ and $\mathrm{H}^{4} \mathrm{NCC}=179.8^{\circ}$ for the $(\mathrm{O}, \mathrm{O})$ one; and $\mathrm{NCC}(=\mathrm{S})=158.4^{\circ}$, $\mathrm{H}^{3} \mathrm{NCC}=-80.8^{\circ}$ and $\mathrm{H}^{4} \mathrm{NCC}=160.3^{\circ}$ for the $(\mathrm{S}, \mathrm{S})$ compound vs. $\mathrm{NCC}(=\mathrm{S})=-131.2^{\circ}, \mathrm{H}^{3} \mathrm{NCC}=-65.7^{\circ}$ and $\mathrm{H}^{4} \mathrm{NCC}=177.9^{\circ}$ for the $(\mathrm{S}, \mathrm{O})$ one. Furthermore, the presence of the $\mathrm{N}: \cdots \mathrm{S}$ interaction is reflected by both an increase of the negative charge on the nitrogen and a slightly positive charge on the thiol sulfur atom, $\mathrm{N} \cdots \mathrm{S}$ being equal to $c a .280 \mathrm{pm} v s$. a sum of the van der Waals radii of $335 \mathrm{pm}$. The atoms N, S and $\mathrm{H}$ were not found to deviate significantly from a straight line in these systems $\left(\mathrm{N} \cdots \mathrm{S}-\mathrm{H} c a .152^{\circ}\right)$, meeting the geometrical criterion of Rosenfield et al. ${ }^{38}$ for a nucleophilic nitrogen approaching an electrophilic sulfur. Consideration of electron correlation was found to be essential for a correct mimetization of this $\mathrm{N}: \cdots \mathrm{S}$ intramolecular interaction (Table 1). This particular nonbonding close contact was previously found by Carey and coworkers ${ }^{39}$ to have a significant stabilising role in acylthioproteases.

The energy difference between the most stable conformation, A/syn/s-cis, and each one of those conformers - G/skew' $/$ s-cis for $(\mathrm{O}, \mathrm{O})$ and $(\mathrm{S}, \mathrm{O})$, and G/antils-cis for $(\mathrm{O}, \mathrm{S})$ and $(\mathrm{S}, \mathrm{S})$ - takes the following values: $12.8 \mathrm{~kJ} \mathrm{~mol}^{-1}$ for $(\mathrm{O}, \mathrm{O}), 1.9$ for $(\mathrm{O}, \mathrm{S}), 13.2$ for $(\mathrm{S}, \mathrm{O})$ and 2.2 for $(\mathrm{S}, \mathrm{S})$ (Table 1). Sensitivity to the position of the oxygen-by-sulfur substitution is then clearly evidenced as, while almost insensitive to introduction of a thione atom, these values decrease by $c a .11 \mathrm{~kJ} \mathrm{~mol}^{-1}$ when $\mathrm{Y}=\mathrm{S}$.

Oxygen-by-sulfur substitutions also discriminate against amine $\cdots$ Y close contact intramolecular interactions occurring in the Alantils-cis conformation (Fig. 3), where the $(\mathrm{N}) \mathrm{H}_{2}$ atoms stand above and below the NCCY ring plane (Fig. 2). This Alantils-cis form results from the most stable one, A/syn/s-cis, by a $180^{\circ}$ rotation around the $\mathrm{C}-\mathrm{C}$ central bond . In fact, for all the molecules studied, both $\mathrm{A} / \mathrm{syn} / \mathrm{s}$-cis and Alantils-cis correspond to minima in the potential-energy

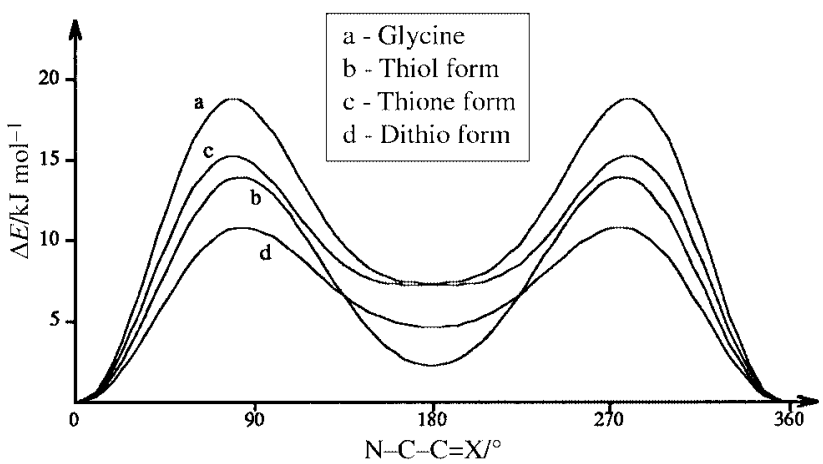

Fig. 4 Potential-energy profile for the internal rotation around the $\mathrm{C}-\mathrm{C}$ bond of the $\mathrm{NH}_{2} \mathrm{CH}_{2} \mathrm{C}(=\mathrm{X}) \mathrm{YH}(\mathrm{X}, \mathrm{Y}=\mathrm{O}$ or S) molecules, at the $3-21 \mathrm{G}\left(\mathrm{N}^{*}\right)$ level of calculation. (Anti and $s$-cis orientations were considered for the nitrogen electron lone pair and the $\mathrm{C}(=\mathrm{X}) \mathrm{YH}$ group respectively. Fourier coefficients (see computational methods) are: $V_{1}=2.1,0.0,2.7$ and $2.5 ; V_{2}=14.7,12.8,11.3$ and 8.5; $V_{3}=5.3,2.3,4.6$ and 2.1 , for the $(\mathrm{O}, \mathrm{O}),(\mathrm{O}, \mathrm{S}),(\mathrm{S}, \mathrm{O})$ and $(\mathrm{S}, \mathrm{S})$ molecules, respectively).

profile for the internal rotation around the $\mathrm{C}-\mathrm{C}$ bond (Fig. 4): at $0^{\circ}$ - for $\mathrm{A} / \mathrm{syn} / \mathrm{s}$-cis, the lowest energy conformer - and $180^{\circ}$ - for Alantils-cis.

In fact, the $A /($ anti - syn $) / s$-cis energy difference takes the following values: $7.0 \mathrm{~kJ} \mathrm{~mol}^{-1}$ for $(\mathrm{O}, \mathrm{O}), 0.8$ for $(\mathrm{O}, \mathrm{S}), 7.9$ for $(\mathrm{S}, \mathrm{O})$ and 3.4 for $(\mathrm{S}, \mathrm{S})$ (Table 1). In turn, the energy barriers for the corresponding $\mathrm{A} / \mathrm{syn} / \mathrm{s}$-cis $\rightarrow$ A/anti/s-cis interconversion are (at the 3-21G(N*) level): $19.1 \mathrm{~kJ} \mathrm{~mol}^{-1}$ for $(\mathrm{O}, \mathrm{O}), 14.1$ for $(\mathrm{O}, \mathrm{S})$, 15.5 for $(\mathrm{S}, \mathrm{O})$ and 11.0 for $(\mathrm{S}, \mathrm{S})$ (Table 1$)$. Interestingly enough, these values, as well as the potential-energy deconvolution profiles obtained for these systems (Fig. 4), seem to suggest that the oxygen-by-sulfur substitution in the $\mathrm{Y}$ position favours those conformations where the $\mathrm{C}-\mathrm{Y}$ bond is eclipsed with either $\mathrm{C}-\mathrm{N}$ or $\mathrm{C}-\mathrm{H}\left(\mathrm{NCCY}=0^{\circ}\right.$ or $\pm 120^{\circ}$, i.e. $\mathrm{C}=\mathrm{X}$ staggered $)-V_{3}$ being lower for $\mathrm{Y}=\mathrm{S}(2.3$ and 2.1 , relative to 5.3 and 4.6 for $\mathrm{Y}=\mathrm{O}$ ). This occurs especially when $\mathrm{X}$ is an oxygen, which is evidenced by the smaller $V_{1}$ values obtained for the $(\mathrm{O}, \mathrm{O})$ and $(\mathrm{O}, \mathrm{S})$ systems (Fig. 4). Moreover, the decrease of that energy barrier is almost additive with respect to oxygen-bysulfur substitutions in both the thiol and the thione positions, $V_{2}$ displaying a steady decrease when going from $(\mathrm{O}, \mathrm{O})$ to $(\mathrm{S}, \mathrm{O}),(\mathrm{O}, \mathrm{S})$ and $(\mathrm{S}, \mathrm{S})$ molecules - 14.7, 12.8, 11.3 and 8.5, respectively.

The graphical representation of the dependence of the N-C bond length on the NCCX dihedral angle (Fig. 5(a)) presents minima, i.e. shorter $\mathrm{N}-\mathrm{C}$ values, at $0^{\circ}$ (syn) and $180^{\circ}$ (anti), and a maximum at $c a .90^{\circ}$, with a highest overall variation of approximately $2 \mathrm{pm}$ attained for the thiol compound. The NCC bond angle, in turn, displays an opposite behaviour (Fig. 5(b)), with maxima at $0^{\circ}$ (syn) and $180^{\circ}$ (anti), and a minimum at $c a .90^{\circ}$. This minimum is lowest for $\mathrm{X}=\mathrm{S}$, due to the high sensitivity of the NCC angle to repulsive steric interactions, namely between $-\mathrm{C}=\mathrm{S}$ and $-\mathrm{CH}_{2} \mathrm{NH}_{2}$ molecular fragments. Moreover, a conformation displaying eclipsed $\mathrm{C}-\mathrm{N}$ and $\mathrm{C}-\mathrm{SH}$ bonds corresponds to maximal variations of $\mathrm{NCC}\left(\mathrm{ca} .6^{\circ}\right)$, on account of both steric and electrostatic repulsions (the charge on both the $\mathrm{S}$ thiol and the $(\mathrm{N}) \mathrm{H}$ hydrogen atoms being slightly positive).

The plot of the dependence of the $\mathrm{C}-\mathrm{Y}$ bond length on the $\mathrm{NCC}(=\mathrm{X})$ dihedral angle (Fig. 6(a)) displays minima at $c a . \pm 60^{\circ}$ (gauche) and $180^{\circ}$ (anti), and a peak at ca. $\pm 120^{\circ}$, with a maximum overall variation of more than $1.5 \mathrm{pm}$ for the thiol molecule. As for the CCY bond angle (Fig. 6(b)), whose maximum variation exceeds $2^{\circ}$, the opposite behaviour was observed, with minima at $0^{\circ}$ (syn) and ca. $\pm 120^{\circ}$ (skew), and maxima at $c a . \pm 60^{\circ}$ (gauche) and $180^{\circ}$ (anti).

The plot of the $\mathrm{C}=\mathrm{X}$ bond length as a function of the NCCX dihedral angle, in turn, shows maxima at $\mathrm{ca}$. $\pm 60^{\circ}$ (gauche) and $180^{\circ}$ (anti) and minima at $0^{\circ}\left(\right.$ syn) and ca. $\pm 120^{\circ}$ (skew) 


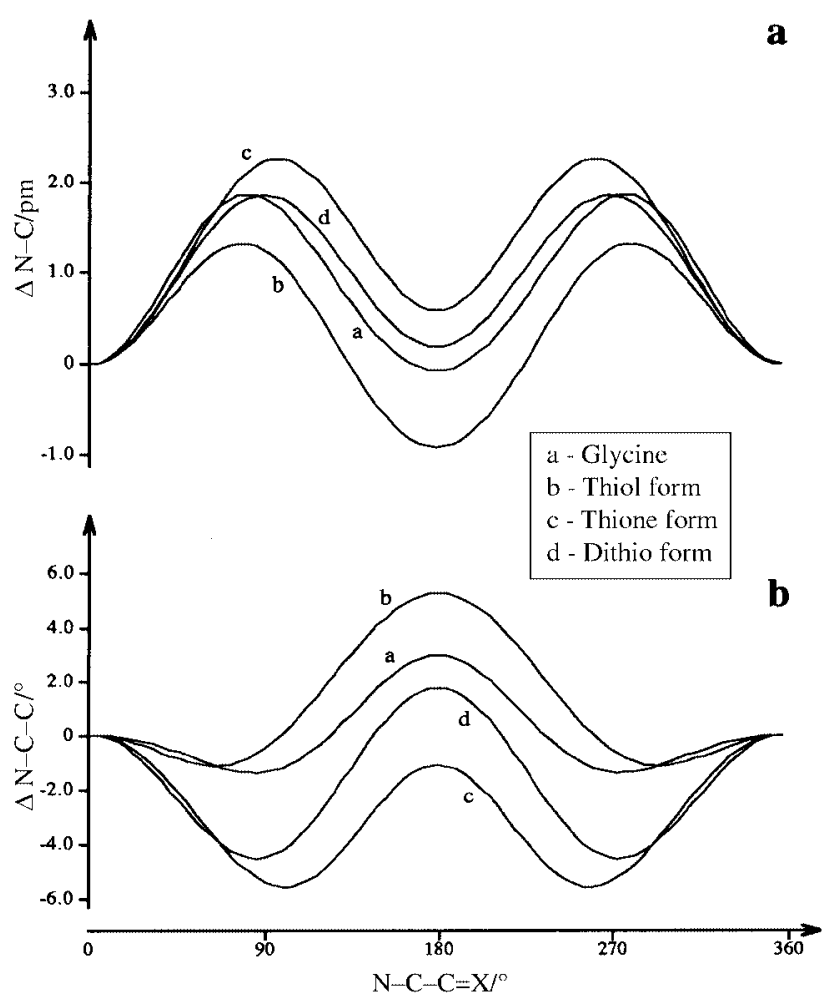

Fig. 5 Graphical representation of the dependence of (a) the N-C bond length and (b) the $\mathrm{N}-\mathrm{C}-\mathrm{C}$ bond angle as a function of the $\mathrm{N}-\mathrm{C}-\mathrm{C}=\mathrm{X}$ dihedral angle, for the $\mathrm{NH}_{2} \mathrm{CH}_{2} \mathrm{C}(=\mathrm{X}) \mathrm{YH}(\mathrm{X}, \mathrm{Y}=\mathrm{O}$ or $\mathrm{S})$ molecules.

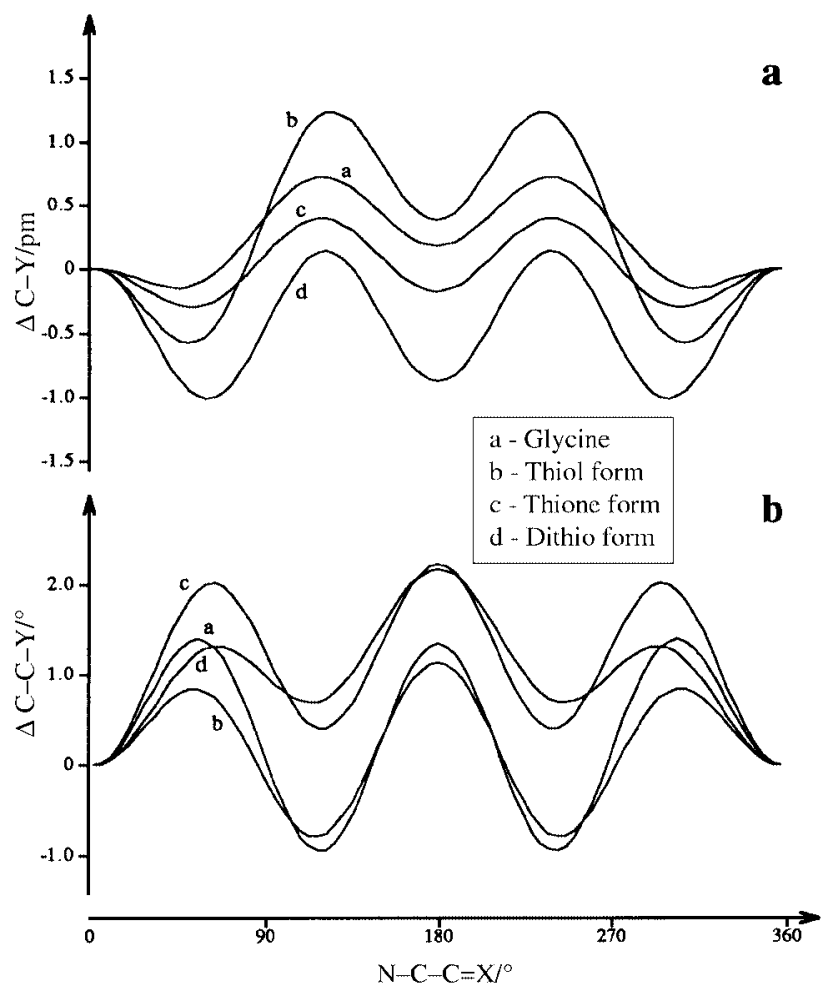

Fig. 6 Graphical representation of the dependence of (a) the $\mathrm{C}-\mathrm{Y}$ bond length and (b) the $\mathrm{C}-\mathrm{C}-\mathrm{Y}$ bond angle as a function of the $\mathrm{N}-\mathrm{C}-\mathrm{C}=\mathrm{X}$ dihedral angle, for the $\mathrm{NH}_{2} \mathrm{CH}_{2} \mathrm{C}(=\mathrm{X}) \mathrm{YH}(\mathrm{X}, \mathrm{Y}=\mathrm{O}$ or $\mathrm{S})$ molecules.

(Fig. 7(a)). In addition, the variation of the $\mathrm{CC}=\mathrm{X}$ bond angle (Fig. 7(b)) exhibits maxima at $0^{\circ}\left(\right.$ syn) and $c a .120^{\circ}$ (skew) and minima at $c a .60^{\circ}$ (gauche) and $180^{\circ}$ (anti). Maximum values of this bond angle suggest the occurrence of steric repulsions between the $-\mathrm{CH}_{2} \mathrm{NH}_{2}$ and $-\mathrm{C}(=\mathrm{X}) \mathrm{YH}(\mathrm{X}, \mathrm{Y}=\mathrm{O}$ or S) moieties

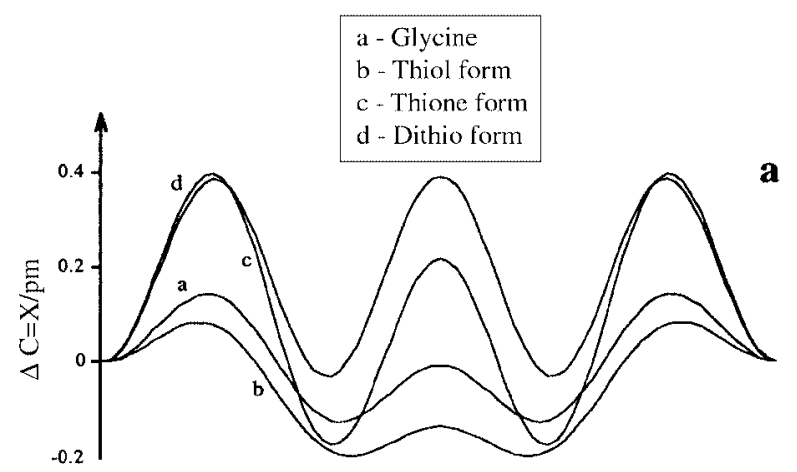

$\mathbf{b}$

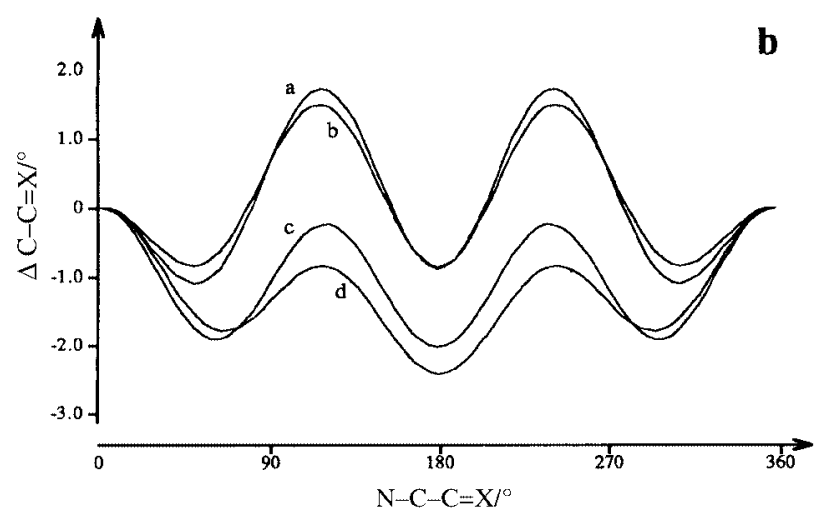

Fig. 7 Graphical representation of the dependence of (a) the $\mathrm{C}=\mathrm{X}$ bond length and (b) the $\mathrm{C}-\mathrm{C}=\mathrm{X}$ bond angle as a function of the $\mathrm{N}-\mathrm{C}-\mathrm{C}=\mathrm{X}$ dihedral angle, for the $\mathrm{NH}_{2} \mathrm{CH}_{2} \mathrm{C}(=\mathrm{X}) \mathrm{YH}(\mathrm{X}, \mathrm{Y}=\mathrm{O}$ or $\mathrm{S})$ molecules.

of the molecules, inasmuch as they are reduced by the opening of those angles.

In summary, the NCC bond angle presents maxima at both $0^{\circ}$ (syn) and $180^{\circ}$ (anti) - when the $\mathrm{N}-\mathrm{C}$ bond is eclipsed by $\mathrm{C}=\mathrm{X}$ or $\mathrm{C}-\mathrm{Y}$ - whereas $\mathrm{CCY}$ exhibits maxima at $c a . \pm 60^{\circ}$ (gauche) and $180^{\circ}$ (anti) - when $\mathrm{C}-\mathrm{Y}$ is eclipsed by $\mathrm{C}-\mathrm{H}$ or $\mathrm{C}-\mathrm{N}$. The CCX bond angle, in turn, displays maxima at $0^{\circ}$ (syn) and $\pm 120^{\circ}$ (skew) - for a $\mathrm{C}-\mathrm{Y}$ bond eclipsed by $\mathrm{C}-\mathrm{H}$ or $\mathrm{C}-\mathrm{N}$. Thus, this skeletal angle variation is mainly determined by the steric hindrances occurring within these molecules.

The Glantils-trans form, which is stabilised by an intramolecular $\mathrm{N} \cdots \mathrm{H}-\mathrm{Y}$ interaction, was found to be the second lowest energy conformer for all the molecules studied, except for the $(\mathrm{O}, \mathrm{S})$ system (Table 1). However, the A/syn/s-cis $\rightarrow$ G/antils-trans interconversion is not an elementary process as it requires intramolecular rotations around more than one bond, namely $\mathrm{N}-\mathrm{C}, \mathrm{C}-\mathrm{C}$ and $\mathrm{C}-\mathrm{Y}-$ and the corresponding energy barrier was not directly evaluated, neither can it be indirectly determined since not enough intermediate conformational states were studied.

When compared to the similar systems propionic acid and its oxygen-by-sulfur substituted derivatives $-\mathrm{CH}_{3} \mathrm{CH}_{2} \mathrm{C}(=\mathrm{X}) \mathrm{YH}$ $(\mathrm{X}, \mathrm{Y}=\mathrm{O}$ or $\mathrm{S})-$ glycine and its thiol and thione analogues $\mathrm{NH}_{2} \mathrm{CH}_{2} \mathrm{C}(=\mathrm{X}) \mathrm{YH}(\mathrm{X}, \mathrm{Y}=\mathrm{O}$ or $\mathrm{S})$ - display a slightly different conformational behaviour. In fact, when considering the $\mathrm{C}-\mathrm{C}$ intramolecular rotation, the latter present energy minima at $0^{\circ}$ and $180^{\circ}$, while propionic acid and its derivatives display minima at $0^{\circ}$ and $120^{\circ} .{ }^{40}$ Moreover, the $\mathrm{NH}_{2} \mathrm{CH}_{2} \mathrm{C}(=\mathrm{X}) \mathrm{YH}$ molecules have lowest minima at $0^{\circ}$, irrespective of $\mathrm{X}$ and $\mathrm{Y}$ being either $\mathrm{O}$ or $\mathrm{S}$, as opposed to the $\mathrm{CH}_{3} \mathrm{CH}_{2} \mathrm{C}(=\mathrm{X}) \mathrm{YH}$ systems, for which the most stable conformers for $\mathrm{X}=\mathrm{S}$ occur for a central dihedral angle of $120^{\circ}$. This particular conformational behaviour of glycine and its analogues is due to the presence of the nitrogen atom, that allows the formation of relevant stabilising intramolecular close contacts - namely in the thiol compounds, where a $\mathrm{N}: \cdots \mathrm{S}(\mathrm{H})$ interaction occurs. 


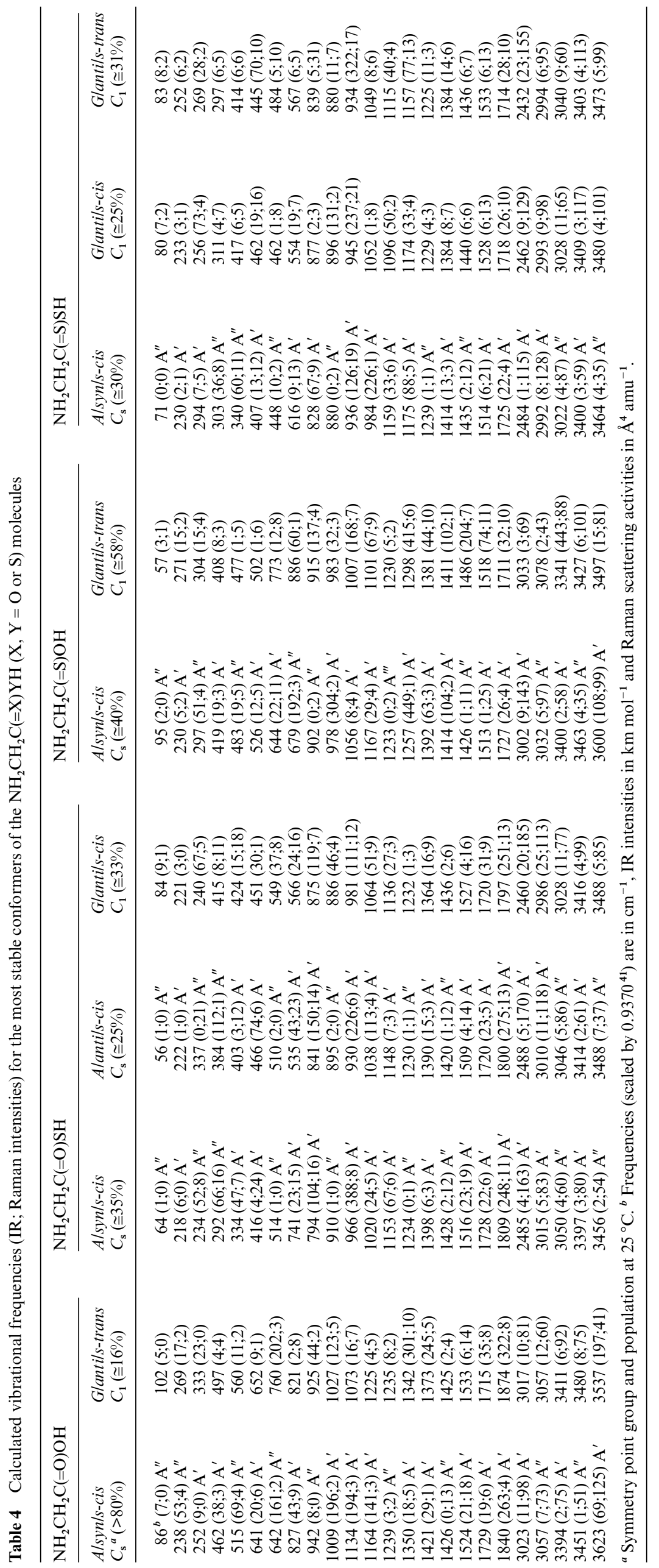




\section{Vibrational spectra}

The effect of oxygen-by-sulfur substitutions on both conformational energy differences and intramolecular interactions have been analysed above. The way they affect vibrational spectra will now be considered.

Table 4 lists the vibrational frequencies, as well as the infrared and Raman intensities, obtained within the harmonic approximation at the HF/6-31G** level, for several conformers of the $\mathrm{NH}_{2} \mathrm{CH}_{2} \mathrm{C}(=\mathrm{X}) \mathrm{YH}(\mathrm{X}, \mathrm{Y}=\mathrm{O}$ or $\mathrm{S})$ molecules.

For glycine $(\mathrm{X}=\mathrm{O}, \mathrm{Y}=\mathrm{O})$, only two conformational levels were found to be appreciably populated, namely: A/syn/s-cis statistical weight, $w=1$; energy difference to the most stable form, $\Delta E=0.0 \mathrm{~kJ} \mathrm{~mol}^{-1}$; Boltzmann population, $\rho>80 \%$ and Glantils-trans - $w=2 ; \Delta E=5.9 \mathrm{~kJ} \mathrm{~mol}^{-1} ; \rho \approx 16 \%$ (Table 1). As referred to previously, A/syn/s-cis and G/anti/s-trans display intramolecular $\mathrm{NH}_{2} \cdots \mathrm{O}=\mathrm{C}$ and $\mathrm{N}: \cdots \mathrm{HO}$ close contacts, respectively (Fig. 2). The $\mathrm{OH}$ stretching frequency of Glanti/s-trans $\left(3537 \mathrm{~cm}^{-1}\right)$ is shifted to a lower value by more than $80 \mathrm{~cm}^{-1}$ relative to the most stable form (Table 4). In addition, its infrared intensity increases almost threefold, while its Raman intensity decreases to approximately one third. These facts seem to suggest that the $\mathrm{N} \cdots \mathrm{HO}$ close contact in the Glantils-trans conformation might correspond, for the $(\mathrm{O}, \mathrm{O})$ molecule, to a hydrogen bond type of interaction. Concurrently with the changes detected in the $\mathrm{OH}$ stretching vibrational mode, this intramolecular interaction is proposed to be also responsible for a blue shift of both the carbonyl stretching band at $1840 \mathrm{~cm}^{-1}$ (by $34 \mathrm{~cm}^{-1}$ ) and (by $18 \mathrm{~cm}^{-1}$ ) of the mode herein tentatively ascribed to the $\mathrm{NH}_{2}$ wagging motion (a very strong infrared mode, whose frequency for the $\mathrm{A} / \mathrm{syn} / \mathrm{s}$-cis conformer was now calculated to be $1009 \mathrm{~cm}^{-1}$ ).

Regarding the $(\mathrm{O}, \mathrm{S})$ molecule, the three most stable conformations, namely, A/syn/s-cis $\left(w=1 ; \Delta E=0.0 \mathrm{~kJ} \mathrm{~mol}{ }^{-1}\right.$; $\rho \approx 35 \%)$, Alanti/s-cis $\left(w=1 ; \Delta E=0.8 \mathrm{~kJ} \mathrm{~mol}^{-1} ; \rho \approx 25 \%\right)$ and Glantils-cis $\left(w=2 ; \Delta E=1.9 \mathrm{~kJ} \mathrm{~mol}^{-1} ; \rho \approx 33 \%\right.$ ) (Table 1), gather $c a .90 \%$ of the total Boltzmann population (assuming that the four most stable levels correspond to $100 \%$ ). As Alanti/s-cis and Glantils-cis are stabilised by $\mathrm{NH}_{2} \cdots \mathrm{S}(\mathrm{H})$ and $\mathrm{N}: \cdots \mathrm{S}(\mathrm{H})$ intramolecular close contacts, respectively, the corresponding $\mathrm{S}-\mathrm{H}$ stretching frequency displays a downward shift (relative to A/syn/s-cis at $2485 \mathrm{~cm}^{-1}$ ) of $25 \mathrm{~cm}^{-1}$ for the latter, while it is almost unchanged for the former $\left(2488 \mathrm{~cm}^{-1}\right)$.

The pattern of vibrational changes exhibited by both $v_{\text {as }}\left(\mathrm{NH}_{2}\right)$ (asymmetric $\mathrm{NH}_{2}$ stretching) and $v_{\mathrm{s}}\left(\mathrm{NH}_{2}\right)$ (symmetric $\mathrm{NH}_{2}$ stretching) in these two relevant excited conformational levels of the $(\mathrm{O}, \mathrm{S})$ molecule is worth mentioning. In fact, these vibrational modes, upward shifted relative to the most stable form (3456 and $3397 \mathrm{~cm}^{-1}$ ), by 32 and $17 \mathrm{~cm}^{-1}$, respectively, display very close frequencies for the two conformers (Alanti/s-cis and G/antils-cis). In turn, both $v_{\text {as }}\left(\mathrm{CH}_{2}\right)$ (asymmetric $\mathrm{CH}_{2}$ stretching) and $v_{\mathrm{s}}\left(\mathrm{CH}_{2}\right)\left(\right.$ symmetric $\mathrm{CH}_{2}$ stretching) are only slightly shifted in the Alantils-cis conformation (3010 and $3046 \mathrm{~cm}^{-1}$ ) and appreciably downward shifted in Glanti/s-cis, by 29 and $22 \mathrm{~cm}^{-1}$, respectively. These facts seem to suggest that, for the $(\mathrm{O}, \mathrm{S})$ molecule, $v_{\mathrm{s}}\left(\mathrm{CH}_{2}\right)$ and $v_{\mathrm{as}}\left(\mathrm{CH}_{2}\right)$ modes act as probes for the : $\mathrm{N}-\mathrm{CC}$ dihedral angle, whereas $v_{\mathrm{s}}\left(\mathrm{NH}_{2}\right)$ and $v_{\mathrm{as}}\left(\mathrm{NH}_{2}\right)$ are more sensitive to the value of $\mathrm{NC}-\mathrm{C}(=\mathrm{O})$. Moreover, the band occurring at $966 \mathrm{~cm}^{-1}$ for A/syn/s-cis, herein ascribed to the $\mathrm{NH}_{2}$ wagging mode, is downward shifted by $36 \mathrm{~cm}^{-1}$ in the Alantils-cis conformation and upward shifted by $15 \mathrm{~cm}^{-1}$ in the Glanti/s-cis form, thus suggesting a specific sensitivity of this vibrational mode to intramolecular interactions involving the nitrogen atom.

For the (S,O) molecule there are only two relevant conformational levels, namely, $A /$ syn/s-cis $\left(w=1 ; \Delta E=0.0 \mathrm{~kJ} \mathrm{~mol}^{-1}\right.$; $\rho \approx 40 \%)$, and G/antils-trans $\left(w=2 ; \Delta E=0.8 \mathrm{~kJ} \mathrm{~mol}^{-1} ; \rho \approx 58 \%\right)$ (Table 1), gathering $c a .98 \%$ of the total Boltzmann population (all the populations being normalized for the three most stable conformers). From Table 4 it can be seen that the $\mathrm{OH}$ stretching band of Glanti/s-trans $\left(3497 \mathrm{~cm}^{-1}\right)$ is shifted to lower frequencies by $103 \mathrm{~cm}^{-1}$, relative to the corresponding value of the most stable conformer $(\mathrm{A} / \mathrm{syn} / \mathrm{s}$-cis $)$. In contrast to the $(\mathrm{O}, \mathrm{O})$ compound, the infrared intensity of this vibrational mode decreases substantially, suggesting that the oxygen-by-sulfur substitution in the $\mathrm{X}$ position might lead to a decrease in the extent of the mesomeric effect in the molecule. Both $v_{\text {as }}\left(\mathrm{NH}_{2}\right)$ $\left(3427 \mathrm{~cm}^{-1}\right)$ and $v_{\mathrm{s}}\left(\mathrm{NH}_{2}\right)\left(3341 \mathrm{~cm}^{-1}\right)$ vibrational modes of the G/antils-trans conformer are downward shifted by 36 and $59 \mathrm{~cm}^{-1}$, respectively, relative to the corresponding frequencies of the most stable form. $v_{\text {as }}\left(\mathrm{CH}_{2}\right)\left(3078 \mathrm{~cm}^{-1}\right)$ and $v_{\mathrm{s}}\left(\mathrm{CH}_{2}\right)$ $\left(3033 \mathrm{~cm}^{-1}\right)$, in turn, are upward shifted by 46 and $31 \mathrm{~cm}^{-1}$. In this case, clear-cut patterns of conformationally induced vibrational changes are difficult to discern, since all the relevant dihedral angles change from A/syn/s-cis to G/anti/s-trans conformations. Similarly to the $(\mathrm{O}, \mathrm{O})$ and $(\mathrm{O}, \mathrm{S})$ molecules, the band occurring at $978 \mathrm{~cm}^{-1}$ for $A /$ syn/s-cis in the $(\mathrm{S}, \mathrm{O})$ molecule, herein tentatively ascribed to the $\mathrm{NH}_{2}$ wagging mode, is upward shifted by $29 \mathrm{~cm}^{-1}$ in the Glantils-trans form.

As for the (S,S) molecule, three appreciably populated conformational levels occur, namely, A/syn $/$ s-cis $(w=1 ; \Delta E=0.0 \mathrm{~kJ}$ $\left.\mathrm{mol}^{-1} ; \rho \approx 30 \%\right)$, Glantils-trans $\left(w=2 ; \Delta E=1.6 \mathrm{~kJ} \mathrm{~mol}^{-1}\right.$; $\rho \approx 31 \%)$ and Glantils-cis $\left(w=2 ; \Delta E=2.2 \mathrm{~kJ} \mathrm{~mol}^{-1} ; \rho \approx 25 \%\right)$ (Table 1) (the populations being normalized for the five most stable conformers). For the two G/anti conformers, the Raman intensities of both $v_{\text {as }}\left(\mathrm{NH}_{2}\right)\left(c a .3476 \mathrm{~cm}^{-1}\right)$ and $v_{\mathrm{s}}\left(\mathrm{NH}_{2}\right)$ (ca. $3406 \mathrm{~cm}^{-1}$ ) modes increase appreciably with respect to the corresponding values for the most stable form, A/syn/s-cis (Table 4). In addition, $v(\mathrm{SH})$ is downward shifted by $52 \mathrm{~cm}^{-1}$ $\left(2432 \mathrm{~cm}^{-1}\right)$ and $22 \mathrm{~cm}^{-1}\left(2462 \mathrm{~cm}^{-1}\right)$ for Glantils-trans and Glanti/s-cis, respectively. The relative magnitudes of these shifts are consonant with the nature of the intramolecular interactions occurring in these conformers.

\section{Conclusion}

The conformational preferences of both glycine and its sulfur analogues were found to be significantly sensitive to oxygen-bysulfur substitutions, either in the $\mathrm{X}$ or in the $\mathrm{Y}$ position (or in both), the conformers obtained being mainly determined by the interplay of distinct intramolecular close contacts. Among these, $\mathrm{N}: \cdots \mathrm{H}(\mathrm{S})$ and $\mathrm{N}: \cdots \mathrm{S}(\mathrm{H})$ are particularly interesting, the latter opposing the unfavourable $\mathrm{N}: \cdots \mathrm{O}(\mathrm{H})$ interactions (in accordance with previous theoretical studies on glycine ${ }^{29}$ ). It is worth noticing that while the $\mathrm{N}: \cdots \mathrm{H}(\mathrm{S})$ close contact is weaker than the $\mathrm{N}: \cdots \mathrm{H}(\mathrm{O})$ one, $\mathrm{N}: \cdots \mathrm{S}(\mathrm{H})$ is a stabilising interaction in contrast to the $\mathrm{N}: \cdots \mathrm{O}(\mathrm{H})$ one. A direct consequence of this kind of energetically favourable close contact is the stabilisation of the G/anti conformations for $\mathrm{X}=\mathrm{S}$ and/or $\mathrm{Y}=\mathrm{S}$.

\section{Acknowledgements}

The authors acknowledge financial support from the Fundação para a Ciência e a Tecnologia, Portugal.

\section{References}

1 S. Vishveshwara and J. A. Pople, J. Am. Chem. Soc., 1977, 99, 2422.

2 H. L. Sellers and L. Schäfer, J. Am. Chem. Soc., 1978, 100, 7728.

3 R. D. Brown, P. D. Godfrey, J. W. V. Storey and M. P. Bassez, J. Chem. Soc., Chem. Commun., 1978, 338.

4 R. D. Suenram and F. J. Lovas, J. Mol. Spectrosc., 1978, 72, 372.

5 R. D. Suenram and F. J. Lovas, J. Am. Chem. Soc., 1980, 102, 7180

6 R. D. Brown, P. D. Godfrey, J. W. V. Storey and M. P. Bassez, J. Chem. Soc., Chem. Commun., 1978, 547.

7 L. R. Wright and R. F. Borkman, J. Am. Chem. Soc., 1980, 102, 6207.

8 L. Schäfer, H. L. Sellers, F. J. Lovas and R. D. Suenram, J. Am. Chem. Soc., 1980, 102, 6566.

9 P. Palla, C. Petrongolo and J. Tomasi, J. Phys. Chem., 1980, 84, 435 10 P. R. Laurence and C. Thomson, Theor. Chim. Acta, 1981, 58, 121. 
11 C. E. Dykstra, R. A. Chiles and M. D. Garrett, J. Comput. Chem., 1981, 2, 266

12 S. Millefiori and A. Millefiori, J. Mol. Struct., 1983, 91, 391.

13 R. Bonaccorsi, P. Palla and J. Tomasi, J. Am. Chem. Soc., 1984, 106, 1945.

14 K. Siam, V. J. Klimkowski, J. D. Ewbank, C. Van Alsenoy and L. Schäfer, J. Mol. Struct., 1984, 110, 171

15 M. Masamuea, J. Mol. Struct., 1987, 152, 293.

16 M. Ramek, Int. J. Quantum Chem., Quantum Biol. Symp., 1990, 17, 45.

17 M. Ramek, V. K. W. Cheng, R. F. Frey, S. Q. Newton and L. Schäfer, J. Mol. Struct. (THEOCHEM), 1991, 235, 1.

18 J. H. Jensen and M. S. Gordon, J. Am. Chem. Soc., 1991, 113, 7917.

19 K. Iijima, K. Tanaka and S. Onuma, J. Mol. Struct., 1991, 246, 257.

20 D. Yu, D. A. Armstrong and A. Rauk, Can. J. Chem., 1992, 70 1762.

21 Y. Ding and K. Krogh-Jespersen, Chem. Phys. Lett., 1992, 199, 261.

22 M. Ramek and V. K. W. Cheng, Int. J. Quantum Chem., Quantum Biol. Symp., 1992, 19, 15.

23 R. F. Frey, J. Coffin, S. Q. Newon, M. Ramek, V. K. W. Cheng, F. A. Momany and L. Schäfer, J. Am. Chem. Soc., 1992, 114, 5369.

24 A. G. Császár, J. Am. Chem. Soc., 1992, 114, 9568.

25 C.-H. Hu, M. Shen and H. F. Schaefer III, J. Am. Chem. Soc., 1993 115, 2923.

26 I. D. Reva, A. M. Plokhotnichenko, S. G. Stepanian, A. Y. Ivanov, E. D. Radchenko, G. G. Sheina and Y. P. Blagoi, Chem. Phys. Lett., 1995, 232, 141.

27 P. D. Godfrey and R. D. Brown, J. Am. Chem. Soc., 1995, 117, 2019

28 P. D. Godfrey, R. D. Brown and F. M. Rodgers, J. Mol. Struct., 1996, 376, 65.

29 D. T. Nguyen, A. C. Scheiner, J. W. Andzelm, S. Sirois, D. R. Salahub and A. T. Hagler, J. Comput. Chem., 1997, 18, 1609.
30 P. J. Tonge, R. Ménard, A. C. Storer, B. P. Ruzsicska and P. R. Carey, J. Am. Chem. Soc., 1991, 113, 4297.

31 P. R. Carey and P. J. Tonge, Acc. Chem. Res., 1995, 28, 8 and references therein.

32 GAUSSIAN 94, Revision B.2, M. J. Frisch, G. W. Trucks, H. B. Schlegel, P. M. W. Gill, B. G. Johnson, M. A. Robb, J. R. Cheeseman, T. Keith, G. A. Petersson, J. A. Montgomery, K. Raghavachari, M. A. Al-Laham, V. G. Zakrzewski, J. V. Ortiz, J. B. Foresman, C. Y. Peng, P. Y. Ayala, W. Chen, M. W. Wong, J. L. Andres, E. S. Replogle, R. Gomperts, R. L. Martin, D. J. Fox, J. S. Binkley, D. J. Defrees, J. Baker, J. P. Stewart, M. Head-Gordon, C. Gonzalez and J. A. Pople, Gaussian Inc., 1995, Pittsburgh, PA.

33 J. S. Binkley, J. A. Pople and W. J. Hehre, J. Am. Chem. Soc., 1980, 102, 939.

34 M. S. Gordon, J. S. Binkley, J. A. Pople, W. J. Pietro and W. J. Hehre, J. Am. Chem. Soc. 1982, 104, 2797.

35 P. C. Hariharan and J. A. Pople, Theor. Chim. Acta, 1973, 28, 213.

36 M. M. Francl, W. J. Pietro, W. J. Hehre, J. S. Binkley, M. S. Gordon, D. J. DeFrees and J. A. Pople, J. Chem. Phys., 1982, 77, 3654.

37 C. Peng, P. Y. Ayala, H. B. Schlegel and M. J. Frisch, J. Comput. Chem., 1996, 17, 49.

38 R. E. Rosenfield, R. Parthasarathy and J. D. Dunitz, J. Am. Chem. Soc., 1977, 99, 4860.

39 K. I. Varughese, A. C. Storer and P. R. Carey, J. Am. Chem. Soc., 1984, 106, 8252.

40 L. A. E. Batista de Carvalho, J. J. C. Teixeira-Dias and R. Fausto, J. Mol. Struct. (THEOCHEM), 1990, 208, 109.

41 A. P. Scott and L. Radom, J. Phys. Chem., 1996, 100, 16502.

Paper $9 / 05073 \mathrm{~F}$ 